\title{
Current Trends in the Philippines' Shrimp Aquaculture Industry:A Booming Blue Economy in the Pacific
}

\author{
Joseph Carlo V Vergel* \\ Molecular Biology and Biotechnology Laboratory, University of Santo Tomas, Philippines
}

Submission: October 30, 2017; Published: December 22, 2017

*Corresponding author: : Joseph Carlo V Vergel, Molecular Biology and Biotechnology Laboratory, Room 405, Research Center for the Natural and Applied Sciences, Thomas Aquinas Research Complex, University of Santo Tomas, España, Manila, 1015, Philippines, Email: vergelcarl@gmail.com

\begin{abstract}
Shrimp aquaculture industry is an important source of income in the inter-tropical countries of Southeast Asia and other inter-tropical developing countries. The shrimp industry has grown rapidly and generates billions of dollars every year in trade and employs millions of people globally. World production of shrimp both captured and farmed is around 7 million metric tons. Shrimp is one of the most important internationally traded fishery commodities in terms of value. Annual reports show that exports of shrimp are currently worth more than 10 billion US dollars or $16 \%$ of all fishery exports. Currently, about $40 \%$ of the world catch of shrimp is from farming. However, the proportion of farmed shrimp in international trade appears to be much higher. The industry boomed rapidly in the Pacific particularly in the Southeast Asian region specifically in countries like the Philippines, Vietnam, Thailand, Indonesia, and Myanmar among others. The Philippines currently ranks $11^{\text {th }}$ in world aquaculture production of fish, crustaceans, molluscs, etc. by principal producers in the latest report released by FAO in 2013 having 0.815 million metric tons of total aquaculture production and a $1.16 \%$ share to the global production of 70.2 million metric tons. The country's total aquaculture production has amounted to over 1.98 billion US dollars. This study presents the current situation of the Philippines' Shrimp Aquaculture Industry. This study is the first to correlate Shrimp Aquaculture Industry and the Blue Economy in the Philippines. Moreover, it presents the issues and challenges of the industry and hopes that all of the stakeholders will work hand in hand to achieve a more progressive Aquaculture Industry.
\end{abstract}

Keywords: Shrimp aquaculture industry; Blue economy; Penaeus monodon; Litopenaeus vanname

\section{The Philippines' Shrimp Aquaculture Profile}

In the Philippines, shrimp farming started in the 1980's. It was in the year 1992, when the Philippines produced the largest shrimp catch of about 120,000 metric tons [1]. This made the Philippines known to the world as one of the leading shrimp producing countries. The biggest share of shrimp harvest in the Philippines comes from the brackish water ponds with contribution from marine fish cages and marine fish pens. There are 271 brackish water shrimp farms $(3,617.8$ ha) registered at the Bureau of Fisheries and Aquatic Resources of the Philippines as of 2013. Penaeus monodon (Black Tiger prawn), an export commodity of the country is cultured in $48 \%(1,772.6 \mathrm{ha})$ of the overall recorded shrimp farms, mostly are polycultured with fish specifically Chanoschanos (Milkfish). Litopenaeus vannamei (Pacific White shrimp) are cultured in 27\% (909.4ha) of the total shrimp farms while the remaining 25\% (935.8ha) are cultured with other endeavor shrimps which is secondary to Oreochromis niloticus (Tilapia) and milkfish and some are involved in polyculture with crabs (Table 1) [2].
Table 1: Shrimp Aquaculture Production in the Philippines in 2014.

\begin{tabular}{|c|c|c|}
\hline Shrimp Species & No. of Farms & $\begin{array}{c}\text { Productive Area } \\
\text { (ha) }\end{array}$ \\
\hline Penaeusmonodon* & 40 & 232 \\
\hline $\begin{array}{c}\text { Litopenaeusvanamei** }^{*} \\
\text { Polyculture (P. monodon+ } \\
\text { fish) }\end{array}$ & 53 & 233.8 \\
\hline $\begin{array}{c}\text { Polyculture (L. vannamei+ } \\
\text { fish) }\end{array}$ & 17 & 1507.5 \\
\hline P. monodon \& L. vannamei & 4 & 642.7 \\
\hline Other shrimp species & 70 & 33 \\
\hline Total & 271 & 3617.8 \\
\hline
\end{tabular}

Note: ${ }^{*} 12$ farms showed no data on productive area; ${ }^{*} 18$ farms showed no data on productive area.

Source: Bureau of Fisheries and Aquatic Resources, Philippines (BFAR). 


\section{Oceanography \& Fisheries Open access Journal}

PH Fisheries-Aquaculture Industry in the Global Perspective

Based from the Philippine Fisheries Profile 2014, a study conducted by the Bureau of Fisheries and Aquatic Resources, Department of Agriculture and Fisheries of the Republic of the Philippines, The Philippines ranked $11^{\text {th }}$ worldwide in the world aquaculture production of fish, crustaceans, mollusks, etc. by principal producers. The Philippines produced a total of
$815,008 \mathrm{MT}$ and has global percentage share of $1.16 \%$. It is valued at about 1.98 billion USD and has a global percentage share of $1.31 \%$ (Table 2). The fisheries sector including the aquaculture fisheries sub-sector boosts the country's Gross Domestic Product (GDP) at $1.6 \%$ and $1.8 \%$ at current and constant 2000 prices respectively. These values translate to some stunning 197 billion PHP for current prices and 130 billion PHP for constant prices of the country's GDP of 12,643 billion PHP (current prices) and 7,164 billion PHP (constant prices).

Table 2: World Aquaculture Production of Fish, Crustaceans, Mollusks, etc., by Principal Producers in 2014.

\begin{tabular}{|c|c|c|c|c|c|}
\hline S. No & Major Countries & Volume (MT) & \% Share & Value (USD `000) & \% Share \\
\hline 1. & China & $45,468,960$ & 61.62 & $73,286,123$ & 45.76 \\
\hline 2. & India & $4,881,019$ & 6.62 & $10,768,427$ & 6.72 \\
\hline 3. & Indonesia & $4,253,896$ & 5.77 & $8,888,092$ & 4.55 \\
\hline 4. & Vietnam & $3,397,064$ & 4.6 & $7,172,905$ & 3.03 \\
\hline 5 & Bangladesh & $1,956,925$ & 2.65 & $4,853,274$ & 4.41 \\
\hline 6. & Norway & $1,332,497$ & 1.81 & $7,068,255$ & 6.42 \\
\hline 7. & Chile & $1,214,523$ & 1.65 & $10,276,077$ & 1.26 \\
\hline 8. & Egypt & $1,137,091$ & 1.54 & $2,024,816$ & 1.17 \\
\hline 9. & Myanmar & 962,156 & 1.3 & $1,867,578$ & 1.65 \\
\hline 10. & Thailand & 934,758 & 1.27 & $2,635,642$ & 1.17 \\
\hline 11. & Philippines & 788,029 & 1.07 & $1,879,579$ & 2.27 \\
\hline 12. & Japan & 657,000 & 0.89 & $3,633,147$ & 0.96 \\
\hline 13. & Brazil & 561,803 & 0.76 & $1,531,827$ & 1.04 \\
\hline 14. & Korea Rep & 480,394 & 0.65 & $1,660,080$ & 0.71 \\
\hline 15. & USA & 425,870 & 0.58 & $1,142,830$ & 13.4 \\
\hline 16. & Other Countries & $5,331,739$ & 7.23 & $21,463,632$ & 100 \\
\hline World Total & $73,783,725$ & 100 & $160,152,283$ & & \\
\hline
\end{tabular}

Note: These countries are those with production of 140,000 tons or more in 2014.

Source: Food and Agriculture Organization (FAO).

Moreover, the foreign trade performance of fishery and aquaculture industry remains impressive. In 2014, it registered a net surplus of 954 million dollars with total export value of 1,274 million USD and import value of 320 million USD. The recorded export volume in 2014 is striking 316,863 MT. The three major highly valued export commodities are Tuna, Seaweeds, and Crustaceans (Crabs \&Shrimps/Prawns). Ranking $3^{\text {rd }}$ most highly valued export commodity, Shrimps contribute 120 million USD to the total export in value in 2014 higher than in 2013 export earnings of 67.5 million USD. Shrimps are exported in fresh, chilled, and frozen forms having a total value of 67 million USD or $56 \%$ of the total shrimp export revenue. Although the 2014 shrimp exports decreased by $6.75 \%$ in volume (MT), it registered a higher record in value of 78\% USD from the previous year's export. Major destination of Philippine shrimp export and fishery product exports (in terms of value) are USA, 25\%; Japan, 15.5\%, Hongkong, 7\%; China, 6.3\%; Germany, 6\%; United Kingdom, 4.3\%; Taiwan, 3.5\%; Spain, 2.5\%; France, 1.1\%; Canada, 1\%; and other countries, $27 \%$ (Figure 1).

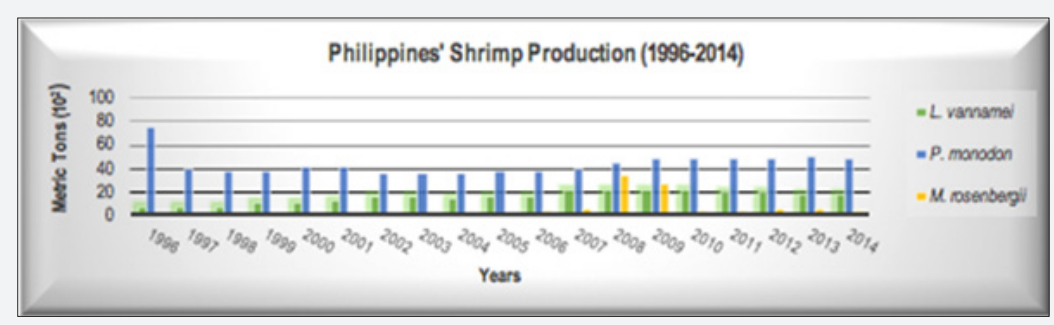

Figure 1: Philippines' Shrimp Productionin 1996-2014.

Source: Philippine Statistics Authority. 
Alongside with the Philippines' fishery and aquaculture export trading is its import performance. The total import value for 2014 was $52 \%$ contributed by three major import commodities namely: $46 \%$ in chilled/frozen fish, $4.7 \%$ in flour, meals, and pellets of fish, crustaceans, and mollusks, and $1.6 \%$ in shrimp feeds. These three major import commodities have an aggregated value of 167 million USD out of the 320 million USD total import value. Shrimp feeds were mostly sourced from Taiwan, 1.6\%; Vietnam, 0.4\%; Thailand, 0.3\%; Malaysia, $0.1 \%$; and Australia, $0.05 \%$ having a total import value of 5.15 million USD.

\section{Towards an Integrated and Sustainable Blue Economy}

In a concept paper published by the United Nations on Blue Economy in 2015, Blue Economy is defined as constituting a sustainable development framework that addresses equity in access to, development of, and the sharing of benefits from marine resources. Comparing to Green Economy, the study reported that Blue Economy also incorporates the same principles of low carbon, resource efficiency, and social inclusion but grounded in a developing world context and fashioned to reflect the circumstances and needs of countries whose future resource base relies on marine/aquatic ecosystems (Figure 2).

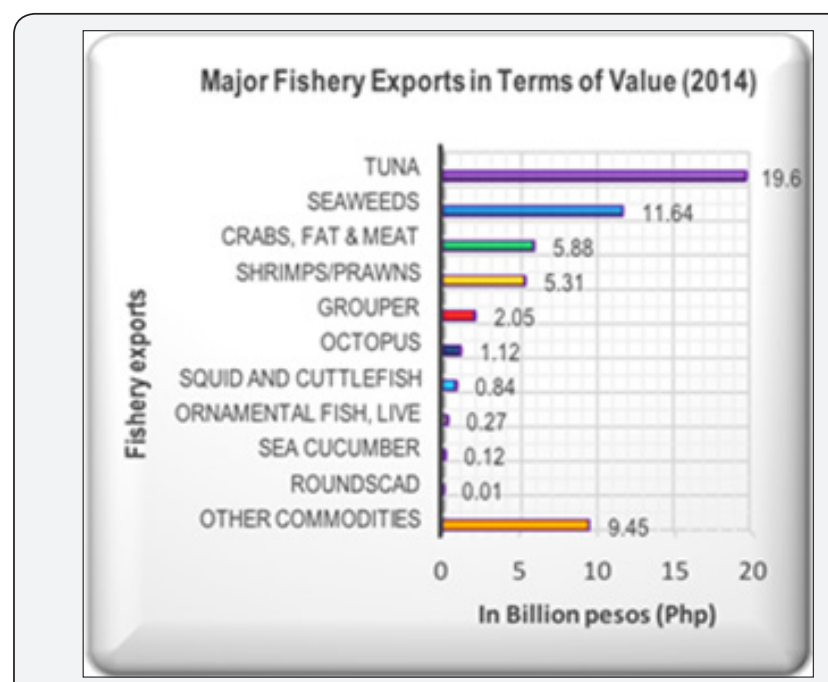

Figure 2: Major Fishery Exports in Terms of Value in 2014 of the Philippines.

Source: Philippine Fisheries Profile 2014.

On the other hand, the Food and Agriculture Organization (FAO) has embraced the concept on Blue Economy and has incorporated it into its Global Initiative on Blue Growth in support of food security, poverty alleviation, and sustainable management of aquatic resources. Moreover, FAO emphasizes that Blue Economy is the central part of the broader sustainable development agenda. Consequently, the Asia Pacific Economic Cooperation views Blue Economy as an approach to advance sustainable management and conservation of ocean and coastal resources and ecosystems and sustainable development in order to foster economic growth.
Just recently during the APEC Ocean-related Ministerial Meeting in 2014, ministers issued the Xiamen Declaration calling for Blue Economy cooperation among countries in the AsiaPacific region, thus, promoting good practices in aquaculture and fisheries and the facilitation of investments in the application of eco-friendly technologies in marine industries. Prior to the 2014 Xiamen Declaration, ministers from the 10 countries namely Cambodia, China, Indonesia, Japan, Lao PDR, The Philippines, RO Korea, Singapore, Timor-Leste, and Vietnam issued the 2012 Changwon Declaration. The countries agreed on a consensus regarding the working definition for Blue Economy as a practical ocean-based economic model using green infrastructure and technologies, innovative financing mechanisms and proactive institutional arrangements for meeting the twin goals of protecting our oceans and coasts and enhancing its potential contribution to sustainable development, including improving human well-being, and reducing environmental risks and ecological scarcities. During the $4^{\text {th }}$ Blue Economy Forum in 2016 held at Haikou, China, the Ocean and Fisheries Working Group (OFWG-APEC) views Blue Economy as an approach to advance sustainable management and conservation of ocean, coastal resources, and ecosystems and to promote sustainable development in order to foster economic growth.

Meanwhile, during the APEC Meeting held in the Philippines in 2015, member economies agreed on a consensus and came up with Iloilo Plan of Action on Food Security and the Blue Economy. The Plan of Action consisted of three specific pillars:

I. Blue Economy towards sustainable food supply chains for food security.

II. Fish loss reduction for increased fish production; and

III. Agribusiness development for food security and inclusive growth.

The consensus gives emphasis on science-based conservation, restoration, enhancement, and management of marine and coastal resources and sustainable aquaculture in the APEC region. The Partnerships in Environmental Management for the Seas of East Asia (PEMSEA) views Blue Economy for business as a set of environmentally and socially sustainable commercial activities, products, services, and investments dependent on and impacting coastal and marine resources. According to PEMSEA, it may not be limited to economic activities in coastal and marine areas but also sustainable activities for a healthy environment, society, and economy.

Moreover, the Philippines, being the chair of the Association of Southeast Asian Nations (ASEAN) in 2017, offer to lead on areas that the country has a track record namely Marine Protected Areas and Networks; Community Engagement including Local Government Units, Non-Government Organizations, and Indigenous People; Seeking and sharing of traditional knowledge; Cooperative Marine Science programs; Ratification of relevant conventions; and Addressing marine litter. 
ASEAN actions were agreed upon three key regional items
A. Fisheries.
B. Aquaculture, and
C. Tourism.

First, ASEAN member nations want to establish a robust and well-managed fisheries sector for local, regional, and international consumption as well as export trade markets. Second, they approved for the need of smart aquaculture that is well-placed and well designed with the help of modern technology in accordance with ASEAN standards. Lastly, the block agreed for the need of real eco-tourism and sustainable tourism infrastructure that give importance to cultural heritage preservation, local communities, and public-private sector participation.

The Fisheries and Aquaculture industry leads other key blue economy industries based on their dependence and impact on coastal and marine areas. Following
a. Fisheries and Aquaculture are:
b. Ports, Shipping, and Marine Transport;
c. Tourism, Resorts, and Coastal Development;
d. Oil and Gas;
e. Coastal Manufacturing;
f. Seabed Mining;
g. Renewable Energy;
h. Marine Biotechnology; and
i. Marine Technology and Environmental Services.

The key elements of a Blue Economy includes
a. Equitable Economic Development;
b. Healthy Ecosystem Services;
c. Integrated Approaches; and
d. Science-based Innovations.

Blue Economy is also not limited to areas covered with water but includes a wider scope which includes many other activities and industries linked to the ocean [3].

\section{Issues and Challenges of the Industry}

Topping the issues and challenges of the Aquaculture industry is

a. Diseases, followed by

b. International market prices;

c. Access to disease-free broodstock;

d. Feed quality and availability;

e. Banned chemicals/antibiotic use;

f. Environmental management; g. International trade barriers;

h. Market coordination; and

i. Public relations management.

As for the Philippines, it was in the early 2000 when different pathogens, hit shrimp farms in the Philippines. Shrimps actively accommodate pathogens as persistent infections that act as a specific memory that functions to specifically reduce the severity of the disease [4]. With this host-viral pathogen interaction, shrimps are capable of carrying single or multiple pathogens at low levels without visible signs of diseases. This allows the shrimps to survive for longer periods of time even though they possess latent infection. Table 2 is a compilation of several crustacean diseases prevalent in the region and its current status in the Philippines.

Several shrimp diseases have been detected in the Philippines. These diseases which cause massive mortality to shrimp population are caused by viruses, bacteria, fungi, and parasites. Based on the Quarterly Aquatic Animal Disease Report (Asia and Pacific Region) 2016 [5], shrimp samples from the Philippines were tested to be positive of White Spot Disease (WSD), Infectious Hypodermal and Haematopoietic Necrosis (IHHN), and Acute Hepatopancreatic Necrosis Disease (AHPND). These diseases are classified as OIE-listed diseases by the World Organization for Animal Health (OIE). Meanwhile, for Non-OIE listed disease, shrimp samples were found to be positive of Hepatopancreatic Microsporidiosis caused by Enterocytozoon hepatopenaei (HPM-EHP). Interestingly, shrimp samples from the Philippines were found to be negative of OIE-listed diseases such as Taura Syndrome (TS), Yellowhead Disease (YHD), Infectious Myonecrosis (IMN), White tail disease (MrNV). Proper mitigation and prevention of diseases must be strategized and put into action by all stakeholders of the industry. Moreover, strengthening Shrimp Biotechnology Research and Development Program is a key to a more progressive Shrimp Aquaculture industry.

Diseases among shrimps caused by several pathogens are the top challenge for Shrimp aquaculture industries worldwide. Shrimp aquaculture has been overwhelmed with a number of trans-boundary aquatic animal diseases caused by viruses, bacteria, fungi, and parasites, with newer pathogens being identified every year. Disease outbreaks have become a significant constraint to the development of Shrimp aquaculture industry, affecting its socioeconomic development, most notably its production worldwide. Therefore, in order to meet the increasing demands of the growing population, new technologies and techniques for disease control must be developed and implemented [6].

\section{Conclusion}

The Shrimp Aquaculture Industry in the Southeast Asian Region particularly in the Philippines is continuously growing and developing. The industry gives the country huge income, 
provides jobs to the people, and secures food supply to the people. It has a very big impact in the economy, society, and environment. ASEAN has a very big potential in the Fisheries and Aquaculture sector given its very strategic location in the world where it is surrounded by different bodies of water. Proper management and governance must be practiced in order to boost the sector where the region is strongest at. The Fisheries and Aquaculture industry is one of the strongest strengths of ASEAN. The Philippines, in particular, is the second largest archipelagic country in the world and most people get their living from the fruits of the ocean, the seas, coastal areas, and aquaculture farms. There may be a lot of challenges in the industry as enumerated in this paper, but the ASEAN community remains to be resilient and strong despite all the issues and challenges bombarding the industry. Cooperation among academic and research institutions, the government, the industry players, and local fishermen/shrimp farmers is a must in establishing a healthy and progressive Fisheries and Aquaculture sector. Each of these sectors must help one another in achieving prosperity in this booming industry. The Fisheries and Aquaculture sector leading the other key industries of the Blue Economy has a very big contribution in achieving food security, poverty alleviation, and sustainable management of marine and aquatic resources in the region. Lastly, translating scientific breakthroughs and innovation into effective policies and actions must be achieved. Working hand in hand among the different stakeholders of the industry is the best plan of action to keep the spirit of Fisheries and Aquaculture igniting [7-15].

\section{Acknowledgement}

The author would like to thank the Department of Science and Technology of the Republic of the Philippines, University of Santo Tomas Graduate School, and University of Santo Tomas Research Center for the Natural and Applied Sciences. The author would like to extend his deepest gratitude to Prof. Mary Beth B. Maningas, Ph.D. for her guidance and support.

\section{References}

1. Philippine Statistics Authority Country STAT Philippines (2017) Philippines' Shrimp Production in 1996-2016.
2. Muegue MFS, Caipang CMA, Geduspan JS (2015) Current status of shrimp aquaculture in the Philippines. Research Signpost pp. 1-17.

3. Whisnart R, Reyes A (2015) Blue Economy for Businesss in East Asia: Towards an Integrated Understanding of Blue Economy. Partnerships in Environmental Management for the Seas of East Asia (PEMSEA), Philippines, pp. 1-68.

4. Flegel $\mathrm{T}$ (2009) Hypothesis for heritable, anti-viral immunity in crustaceans and insects. Biol Direct 4: 32 .

5. Network of Aquaculture Centres in Asia-Pacific, World Organisation for Animal Health (OIE), Regional Representation for Asia and the Pacific, Food and Agriculture Organization of the United Nations (2016) Quarterly Aquatic Animal Disease Report (Asia and Pacific Region), NACA: Bangkok, Thailand and OIE-RRAP, Tokyo, Japan, pp. 1-66.

6. Lima PC, Harris JO, Cook M (2013) Exploring RNAi as a therapeutic strategy for controlling disease in aquaculture. Fish Shellfish Immunol 34(3): 729-743.

7. Asia Pacific Economic Cooperation Ocean and Fisheries Working Group (2014) APEC Marine Sustainable Development Report. pp. 157.

8. Bureau of Fisheries and Aquatic Resources, Philippines (2014) List of Registered Aquaculture Farms in the Philippines. pp. 1-20.

9. Caipang CMA, Bacano-MMBI, Fagutao FF (2015) Biotechnological Advances in Shrimp Heath Management in the Philippines. 1-17.

10. Food and Agriculture Organization (2017) World Aquaculture Production of Fish, Crustaceans, Mollusks, etc., by Principal Producers in 2014. FAO, Canada.

11. FAO (2006) Challenges to International Waters - Regional Assessments in a Global Perspective. Food and Agriculture Organization of the United Nations, Rome, Italy, pp. 1-125.

12. Gillett R (2008) Global Study of Shrimp Fisheries. World Statistics of Fisheries, Aquaculture Department, Food and Agriculture Organization, Rome, Italy, pp. 1-331.

13. Maningas MBB, Kondo H, Hirono I, Saito-TT, Aoki T (2008) Essential function of transglutaminase and clotting protein in shrimp immunity. Mol Immunol 45(5): 1269-1275.

14. Philippine Fisheries Profile (2014) Major Fishery Exports in Terms of Value in 2014 of the Philippines. Bureau of Fisheries and Aquatic Resources, Philippines, pp. 1-70.

15. United Nations (2015) Blue Economy Concept Paper. United Nations Sustainable Development Organization, USA, pp. 1-13.

\section{Your next submission with Juniper Publishers will reach you the below assets}

- Quality Editorial service

- Swift Peer Review

- Reprints availability

- E-prints Service

- Manuscript Podcast for convenient understanding

- Global attainment for your research

- Manuscript accessibility in different formats

( Pdf, E-pub, Full Text, Audio)

- Unceasing customer service

Track the below URL for one-step submission

https://juniperpublishers.com/online-submission.php 